\title{
Safety of Continuous Subcutaneous Insulin Infusion: Metabolic Deterioration and Glycaemic Autoregulation After Deliberate Cessation of Infusion
}

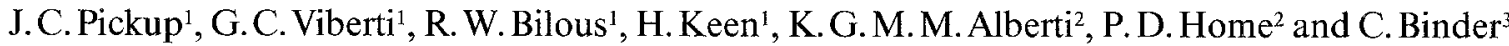 \\ 'Unit for Metabolic Medicine, Guy's Hospital Medical School, London, \\ ${ }^{2}$ Department of Clinical Biochemistry, Royal Victoria Infirmary, Newcastle-upon-Tyne, UK, and \\ ${ }^{3}$ Steno Memorial Hospital, Gentofte, Copenhagen, Denmark
}

\begin{abstract}
Summary. To assess the rate of metabolic deterioration and potential risks of failure of continuous subcutaneous insulin infusion during basal insulin delivery, we deliberately stopped infusion in nine insulin dependent diabetics. Plasma glucose, blood 3-hydroxybutyrate and plasma free insulin were measured for $9 \mathrm{~h}$ whilst the patients remained supine and fasting. Mean plasma glucose remained unchanged at normal fasting levels for the first hour, then rose to plateau at about $10 \mathrm{mmol} / 1$ until the end of the experiment. The final plateau level of glucose varied from patient to patient; two C-peptide secreting diabetics plateaued at low glucose levels. In contrast, blood 3hydroxybutyrate rose progressively, without plateauing. Plasma free insulin concentrations fell during the withdrawal period and there was a highly significant negative correlation between free insulin and 3-hydroxybutyrate. No patient was more than mildly unwell after $9 \mathrm{~h}$ of insulin deprivation. We conclude that under these experimental conditions there is glycaemic autoregulation and that ketones may sometimes be a more appropriate monitor of insulin deficiency or loss of diabetic control than is glucose. Accidental failure of continuous subcutaneous insulin infusion and interruption of basal delivery in resting and fasting diabetics will probably not cause dangerous metabolic or clinical deterioration.
\end{abstract}

Key words: Continuous subcutaneous insulin infusion, insulin withdrawal, ketoacidosis, glucose regulation.

Variable-rate, continuous subcutaneous insulin infusion (CSII) from a portable syringe-pump provides long periods of near-normoglycaemia in most insulin dependent diabetics [1-7]. Outpatient treatment with the device demands a knowledge of its risks. Total failure of the system, for example resulting from accidental withdrawal of the delivery cannula from the subcutaneous site or mechanical failure in a pump could potentially be the most dangerous event, particularly if the resulting insulin withdrawal started soon after the patient went to sleep (and thus continued unnoticed and unmonitored overnight). We have examined the rate of metabolic deterioration which might be expected by deliberately stopping the basal insulin delivery of long-term CSII in nine diabetics of known C-peptide status and measuring over $9 \mathrm{~h}$ plasma concentrations of glucose, 3-hydroxybutyrate and free insulin. The patients were maintained in the resting, fasting, supine state to duplicate overnight conditions. This extends the work of Champion et al. [7] who studied cessation of CSII in four patients with unknown endogenous insulin secretion.

We were also able to correlate the changing clinical responses of the patients with plasma metabolite concentrations, to demonstrate a dissociation in the rates of deterioration in plasma glucose and ketoacid concentration and their relation to plasma free insulin decline, and to evaluate their relative suitability and sensitivity as indices of diabetic control for future metabolic sensing devices.

Preliminary accounts of part of this work have been published $[8,9]$.

\section{Patients and Methods}

Nine fully-informed and consenting insulin dependent diabetics volunteered for the study. Permission was obtained from Guy's Hospital Ethical Committee for the experiments described, which were carried out under conditions of close supervision.

The patients were chosen so as to display a wide range of age, duration of diabetes and insulin dose on CSII or conventional 
Table 1. Clinical features of patients

\begin{tabular}{lllll}
\hline $\begin{array}{l}\text { Patient } \\
\text { number }\end{array}$ & $\begin{array}{l}\text { Age } \\
\text { (years) }\end{array}$ & $\begin{array}{l}\text { Duration of } \\
\text { diabetes } \\
\text { (years) }\end{array}$ & $\begin{array}{l}\text { Insulin dose } \\
\text { on home CSII } \\
\text { (U/day) }\end{array}$ & $\begin{array}{l}\text { C-peptide } \\
\text { status }^{\mathrm{a}}\end{array}$ \\
\hline 1 & 21 & 11 & 54 & - \\
2 & 49 & 24 & 39 & - \\
3 & 30 & 9 & 40 & - \\
4 & 27 & 17 & 60 & - \\
5 & 52 & 6 & 50 & - \\
6 & 26 & 14 & 25 & - \\
7 & 26 & 10 & 51 & - \\
8 & 23 & 1.5 & 44 & + \\
9 & 29 & 10 & 37 & + \\
\hline
\end{tabular}

${ }^{\mathrm{a}}+=$ fasting plasma $\mathrm{C}$-peptide concentration $>0.06 \mathrm{pmol} / \mathrm{ml}$, $\mathrm{CSII}=$ continous subcutaneous insulin infusion

treatment. Their clinical features are shown in detail in Table 1. They were admitted initially for 3-5 days to a metabolic ward for initiation and stabilisation of CSII. The procedures have been described previously [3, 4], but, in brief, Actrapid insulin (Novo), diluted with sterile saline $0.154 \mathrm{~mol} / 1$, was delivered $\mathrm{SC}$ by syringe pump, according to individual insulin requirements. The pump was the model 1001HM Mill Hill Infuser (Muirhead Medical, London) which incorporates a manual advance of the lead screw to deliver metered insulin boosts $30 \mathrm{~min}$ before each main meal. Insulin solution was delivered through a 23 or $25 \mathrm{G}$ Butterfly needle ( $\mathrm{Ab}$ bott Laboratories) which was implanted $\mathrm{SC}$ in the abdominal wall.

After 3 weeks at home on CSII, the patients returned to hospital for the insulin withdrawal experiment. Following an overnight fast, patients voided urine and an indwelling Teflon cannula, inserted into an antecubital vein for blood sampling at least $60 \mathrm{~min}$ before the start of the experiment, was kept patent with saline $0.154 \mathrm{~mol} / 1$. Patients remained supine throughout the test period. At approximately $0900 \mathrm{~h}$ after the first blood sample the insulin delivery cannula was withdrawn, thus terminating CSII. Urine was collected from eight of the nine patients at the end of the study for glucose analysis. Venous blood samples were taken every hour for $9 \mathrm{~h}$ and analysed for plasma glucose and 3-hydroxybutyrate [10]. Glucose in blood and urine was measured by the glucose oxidase method using an Analox GM5 automatic analyser.

Endogenous insulin secretion was assessed on a different occasion by measuring fasting and glucagon-stimulated plasma C-peptide concentrations using a radioimmunoassay (detection limit $0.06 \mathrm{pmol} / 1$, intra-assay coefficient of variation 3\%) [11]. Plasma free insulin was measured by radioimmunoassay, after precipitation of antibody-bound insulin by addition of polyethylene glycol solution (sensitivity $2 \mathrm{mU} / 1$, intra-assay coefficient of variation $9 \%$ ) [12].

Statistical comparisons were made using Student's t test.

\section{Results}

\section{Plasma Glucose}

The mean \pm SEM of the plasma glucose concentrations in the nine patients following insulin withdrawal are shown in Figure 1. Mean glucose concentrations remained unchanged at normal fasting levels for the first hour and then rose over the next $5 \mathrm{~h}$ or so at a di- minishing rate to plateau at about $10 \mathrm{mmol} / 1$ until the end of the observation period. All mean glucose values after $5 \mathrm{~h}$ were significantly higher than the baseline concentration.

The plasma glucose change from baseline in each patient during the $9 \mathrm{~h}$ is shown in Figure 2. All showed progressive slowing of the glucose rise, most reaching a plateau at about $5 \mathrm{~h}$. However, the baseline-to-plateau glucose increment varied between about 2 and $10 \mathrm{mmol} / \mathrm{l}$, and final concentrations between 6.1 and $15.0 \mathrm{mmol} / \mathrm{l}$. Of the patients with the three smallest increments and lowest final levels, two were C-peptide positive and one was $\mathrm{C}$-peptide negative.

The urinary glucose excretion in eight of the patients was measured and varied from nil (No. 6) to $15.1 \mathrm{mmol} / \mathrm{h}$ (No.1). In five patients (Nos.5-9) the excretion was under $0.5 \mathrm{mmol} / \mathrm{h}$.

\section{Blood 3-Hydroxybutyrate}

The mean \pm SEM response of blood 3-hydroxybutyrate concentration to insulin withdrawal is shown in Figure 3. Unlike plasma glucose, mean 3-hydroxybutyrate values rose progressively without reaching a plateau; concentrations were already increased at $1 \mathrm{~h}$, becoming significantly above baseline at $2 \mathrm{~h}$.

\section{Plasma Free Insulin}

Figure 1 shows the means \pm SEM of the plasma free insulin concentrations after stopping CSII in the seven C-peptide negative patients, and the individual free insulin levels in the two C-peptide positive patients. The mean initial free insulin concentration was $11.4 \pm 2.7 \mathrm{mU} / 1$ overall and $8.6 \pm 1.9 \mathrm{mU} / 1$ in the $\mathrm{C}$ peptide negative patients. The initial insulin levels were higher in the two C-peptide secretors (30 and $12.5 \mathrm{mU} / 1$ respectively). In all patients the concentration of free insulin fell during the withdrawal period, reaching a low plateau level at about 5-6 h.

\section{Correlation of Free Insulin, Glucose and 3-Hydroxybutyrate Concentrations}

The log mean plasma glucose concentration at each sampling time point after withdrawing insulin is plotted against the corresponding log mean plasma free insulin value in the upper panel of Figure 4, and similarly for $\log 3$-hydroxybutyrate versus $\log$ insulin in the lower panel. A highly significant negative correlation between log mean free insulin and log mean 3-hydroxybutyrate is found $(r=-0.989, p=<0.001)$. The inverse correlation between log mean free plasma insulin and log mean plasma glucose is also highly significant $(r=0.979, p=<0.001)$ but appears to be 


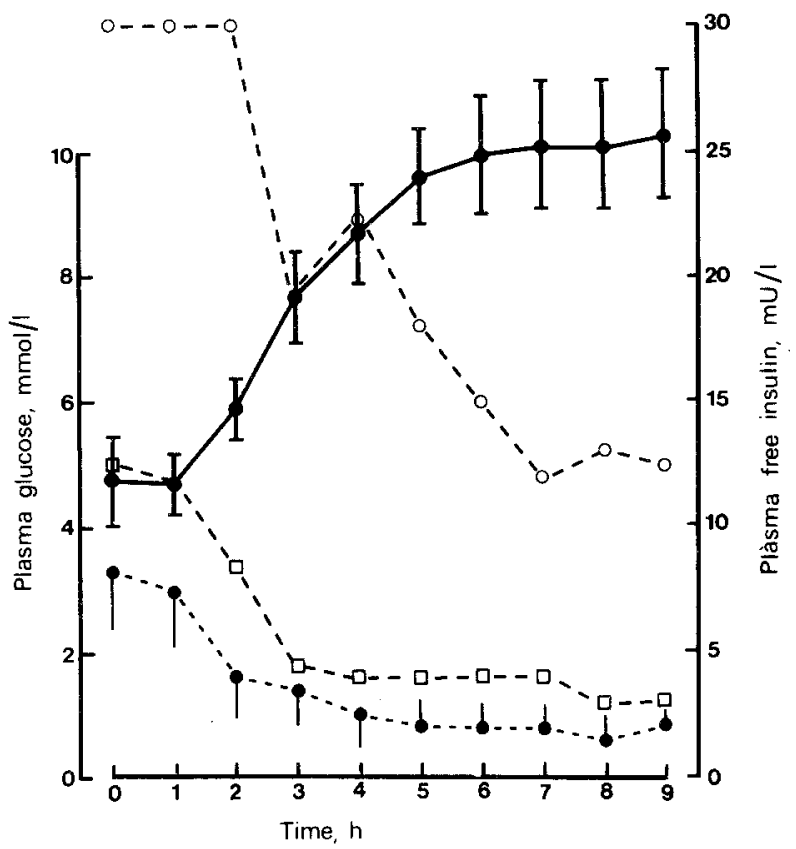

Fig. 1. Plasma glucose concentrations (-_) in nine diabetic patients after deliberate cessation of continuous subcutaneous insulin infusion (mean $\pm \mathrm{SEM}$ ); plasma free insulin concentrations (----) in the seven C-peptide negative patients (mean \pm SEM); plasma free insulin concentrations ( $\mathrm{O}---\mathrm{O})$ in the $\mathrm{C}$-peptide positive patient 9 ; plasma free insulin concentrations $(\square---\square)$ in the $C$ peptide positive patient 8

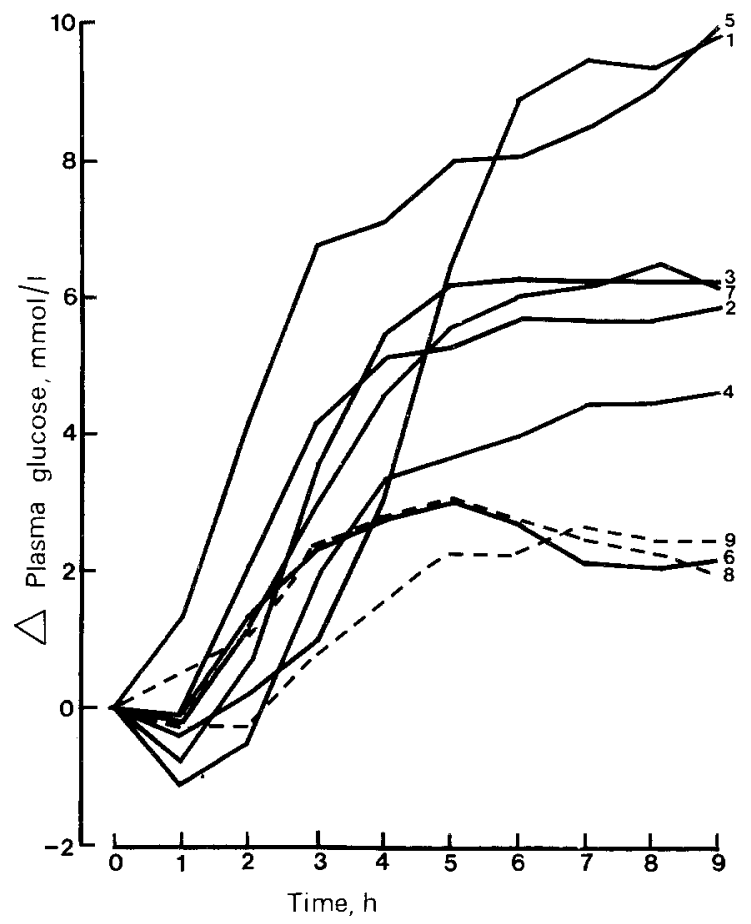

Fig. 2. Change in plasma glucose concentration from baseline after stopping continuous subcutaneous insulin infusion in nine individual patients. Dashed lines represent the C-peptide secreting diabetic patients

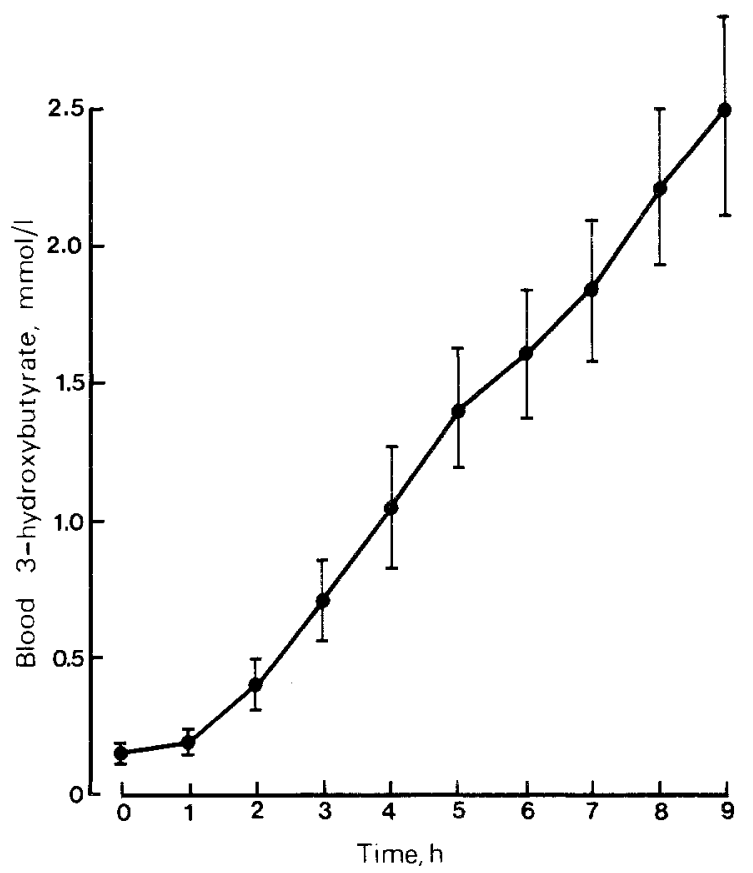

Fig.3. Blood 3-hydroxybutyrate levels in nine diabetic patients after stopping continuous subcutaneous insulin infusion (mean \pm SEM)
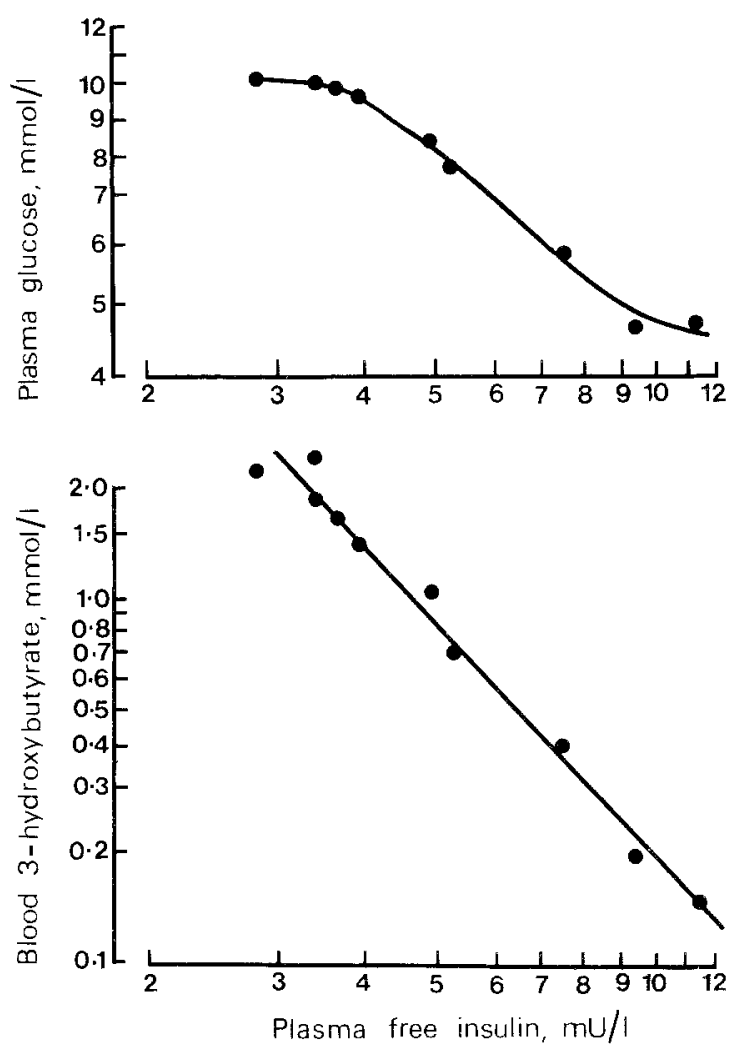

Fig.4. Upper panel: Mean plasma glucose concentrations in all patients plotted against the corresponding mean plasma free insulin concentration at each time point. Lower panel: Mean blood 3-hydroxybutyrate concentrations in all patients plotted against the corresponding mean plasma free insulin level at each time point 
curvilinear, with little change in glucose concentrations below a free insulin value of about $3.5 \mathrm{mU} / 1$.

\section{Clinical State of Patients}

At the end of the 9-h period of exogenous insulin withdrawal, slight nausea and malaise were experienced by two patients, but none of the diabetics felt seriously unwell.

\section{Discussion}

The mode of continuous, low-volume, subcutaneous insulin delivery means that the available reserve of exogenous insulin within the diabetic, under basal conditions, is very small. This may, in part, explain the rarity of clinical hypoglycaemia using CSII [4] but it also creates the risk of rapid total insulin deprivation should the system fail. In earlier study of long-term CSII at home [3], we observed a few episodes of loss of control due to accidental displacement of the implanted insulin delivery cannula. The use of 'winged' infusion needles (such as the 'Butterfly') enables more secure attachment to the skin and is within the capability of the trained patient to reinsert when necessary. Self-monitoring of blood glucose enables early detection of malfunction during waking hours but this may not be so during sleep. In this study we examined the probable metabolic consequences of stopping basal delivery of CSII for $9 \mathrm{~h}$ in insulin-dependent diabetics kept supine and fasting. The experiment was not performed during the night because safety considerations demanded a standard of supervision and care in these unpredictably ketoacidotic patients which was not possible without the full medical and nursing team. Levels of blood glucose and ketones have been recorded during fasts of this duration in non-diabetics [13] and make only a small contribution to the concentrations achieved in this study. For the first hour after stopping the pump plasma glucose remained stable and in the normal range, confirming our previous advice that patients may safely remove the pump for 30-60 min in order to bathe [4].

The plateau in plasma glucose levels at about $5 \mathrm{~h}$ following the progressive rise from basal values has been reported in previous studies of acute withdrawal of intravenously administered insulin [14-16], but has only very recently been emphasised [16]. The final plateau level varied from patient to patient and was related neither to absolute fasting C-peptide nor to final free insulin concentrations. However, two of the three lowest final glucose levels occurred in C-peptide positive diabetics. In this respect, Madsbad et al. [15] have recently shown that C-peptide secreting di- abetics have slower plasma glucose and 3-hydroxybutyrate increases following cessation of intravenously administered insulin.

A possible explanation for the late glucose stabilisation is inhibition of hepatic glucose output by hyperglycaemia itself, an autoregulatory mechanism long suspected and recently suggested experimentally in studies of insulin-induced hypoglycaemia in dogs [17] and man [18]. There is also evidence in normal men rendered insulin and glucagon deficient by somatostatin infusion that hyperglycaemia per se can suppress splanchnic glucose production [19]. If this mechanism is contributing to the plateaux in our study then glycaemic restraint of hepatic glucose production also operates in insulin deficient, diabetic man, although perhaps at a higher glucose level. The recent study of Miles et al. [16] showed a decrease in glucose production (but not ketone bodies) about $2 \mathrm{~h}$ after acute intravenous insulin deprivation.

Increased non-insulin-mediated glucose uptake into cells at raised plasma glucose concentrations may also contribute to the plateau phenomenon as may the level of circulating anti-insulin antibodies [15], late dissociation of insulin from antibodies determining the plateau level. However, it seems unlikely that urinary glucose excretion played a significant role in this study since this was negligible in several patients, whether or not they were C-peptide secretors.

In contrast to plasma glucose, blood 3-hydroxybutyrate rose progressively throughout the study period. Keller et al. [20] have recorded a rise in the turnover of acetoacetate after stopping CSII. This raises doubts about the primacy of glycaemia as the indicator of insulin deficiency or loss of control in diabetics. Registration of progressive rises in ketones might well be a more sensitive monitor; in our study blood 3-hydroxybutyrate (but not glucose) was highly significantly negatively correlated with plasma free insulin across the complete range of values of both variables. Caution should, however, be expressed with respect to free insulin concentrations measured in vitro by the techniques currently available, such as precipitation of antibody-bound insulin by polyethylene glycol (PEG). For example, the binding equilibrium may be disturbed by PEG addition, and may not in any case reflect the ratio of free to bound insulin in vivo, at a given moment.

The minimal clinical deterioration at the end of the $9 \mathrm{~h}$ withdrawal period was reassuring in respect of the safety of CSII under resting conditions. The data of Champion et al. [7], who studied abrupt cessation of CSII in four diabetics of unspecified C-peptide status, support this optimism. One patient in the Champion study developed nausea after $12 \mathrm{~h}$ but the mild 
ketoacidosis was quickly corrected in all by resumption of insulin infusion. Nevertheless, in the active, fed or stressed patient (e.g. during intercurrent illness), metabolic deterioration following insulin delivery failure may be more rapid than that described here, partly because of counter-regulatory hormone surges. There is still, therefore, a pressing need for the development of continuous metabolic sensing devices which in the simplest form could provide an early qualitative warning of progressive loss of diabetic control.

Acknowledgements. We are grateful to Miss A.Collins, Mr. D. Mackintosh and Dr. J.Burrin for skilful technical assistance. JCP and RWB were supported by the Medical Research Council, GCV is a Wellcome Senior Research Fellow and PDH a Novo Research Fellow. The British Diabetic Association is thanked for additional financial support.

\section{References}

1. Pickup JC, Keen H, Parsons JA, Alberti KGMM(1978) Continuous subcutaneous insulin infusion: an approach to achieving normoglycaemia. Br Med J 1: 204-207

2. Pickup JC, Keen H, Parsons JA, Alberti KGMM, Rowe AS (1979) Continuous subcutaneous insulin infusion: improved blood glucose and intermediary metabolite control in diabetics. Lancet $\mathrm{I}:$ : $255-1258$

3. Pickup JC, White MC, Keen H, Kohner EM, Parsons JA, Alberti KGMM (1979) Long-term continuous subcutaneous insulin infusion in diabetics at home. Lancet 2:870-873

4. Pickup JC, Keen H, Viberti GC, White MC, Kohner EM, Parsons JA, Alberti KGMM (1980) Continuous subcutaneous insulin infusion in the treatment of diabetes mellitus. Diabetes Care 3: 290-300

5. Tamborlane WV, Sherwin RS, Genel M, Felig P(1979) Reduction to normal of plasma glucose in juvenile diabetes by subcutaneous administration of insulin with a portable infusion pump. N Engl J Med 300: 573-578

6. Tamborlane WV, Sherwin RS, Genel M, Felig P (1980) Outpatient treatment of juvenile-onset diabetes with a preprogrammed portable subcutaneous insulin infusion system. Am J Med 68: 190-196

7. Champion MC, Shepherd GAA, Rodger NW, Dupré J (1980) Continuous subcutaneous insulin infusion in the management of diabetes mellitus. Diabetes 29: 206-212

8. Pickup JC, Viberti GC, Bilous RW, Dalton N, Binder C, Bloom SR, Keen H (1980) Metabolic and hormonal decompensation after deliberate withdrawal of prolonged subcutaneous insulin infusion. Diabetologia 19:563 (Abstract)

9. Keen H, Pickup JC, Viberti GC, Bilous R, Williams G (1981) Aspects of continuous subcutaneous insulin infusion (CSII) in diabetes. Diabetes Care 4: 54-57

10. Lloyd B, Burrin J, Smythe P, Alberti KGMM (1978) Enzymatic fluorimetric continuous flow assays for blood glucose, lactate, pyruvate, alanine, glycerol and 3-hydroxybutyrate. Clin Chem 24: 1724-1729

11. Faber OK, Binder C (1977) C-peptide response to glucagon. A test for the residual $\beta$-cell function in diabetes mellitus. Diabetes 26:605-610

12. Nakagawa S, Nakayama H, Sossaki T, Yoshimo K, Yu Y, Shimozaki K, Aoki S, Mashimo K (1973) Simple method for the determination of serum free insulin levels in insulin treated pa* tients. Diabetes 22: 590-600

13. Cahill GF, Hernera MG, Morgan AP, Soeldner JS, Steinke J, Levy PL, Reichard GA, Kipnis DM (1966) Hormone-fuel interrelationships during fasting. J Clin Invest 45: 1751-1769

14. Barnes AJ, Bloom SR, Alberti KGMM, Smythe P, Alford FP, Chisholm DJ (1977) Ketoacidosis in pancreatectomised man. N Engl J Med 296: 1250-1253

15. Madsbad S, Alberti KGMM, Binder C, Burrin JM, Faber OK, Krarup T, Regeur L (1979) Role of residual insulin secretion in protecting against ketoacidosis in insulin-dependent diabetes. Br Med J 2: 1257-1259

16. Miles JM, Rizza RA, Haymond MW, Gerich JE (1980) Effects of acute insulin deficiency on glucose and ketone body turnover in man. Diabetes 28:926-930

17. Sacca L, Cryer PE, Sherwin RS (1979) Blood glucose regulates the effects of insulin and counterregulatory hormones on glucose production in vivo. Diabetes 28: 533-536

18. Sacca L, Sherwin RS, Hendler R, Felig P (1979) Influence of continuous physiologic hyperinsulinemia on glucose kinetics and counter-regulatory hormones in normal and diabetic humans. J Clin Invest 63:849-857

19. Liljenquist JE, Mueller GL, Cherrington AD, Perry JM, Rabinowitz D (1979) Hyperglycaemia per se (insulin and glucagon withdrawn) can inhibit hepatic glucose production in man. $J$ Clin Endocrinol Metab 48: 171-175

20. Keller U, Sonnenberg GE, Berger W (1981) Ketone body turnover rates in insulin-dependent diabetics following short-term withdrawal of a continuous S.C. infusion of insulin. Eur J Clin Invest (in press)

Received: 15 May 1981

and in revised form: 25 August 1981

Dr. J.C. Pickup

Unit for Metabolic Medicine

Guy's Hospital Medical School

London, SE1, 9RT UK 